Çetinkaya, F. Ç., Topçam, A. B. ve Sönmez, M. (2019). Drama yönteminin sınıf öğretmeni adaylarının masal yazma becerilerine etkisi. Ana Dili Eğitimi Dergisi, 7(2), 337-352.

Ana Dili Eğitimi Dergisi
Journal of Mother Tongue Education
www.anadiliegitimi.com

\title{
Drama Yönteminin Sınıf Öğretmeni Adaylarının Masal Yazma Becerilerine Etkisi
}

\author{
Fatih Çetin ÇETINKAYA* \\ Abdurrahman Baki TOPÇAM** \\ Muhammet SÖNMEZ ${ }^{* * *}$
}

\begin{abstract}
Öz
Bu araştırmanın amacı sınıf öğretmeni adaylarının oluşturmacı yazma ve drama ile hikâye oluşturma yöntemi kullanılarak yazdıkları masalları değerlendirmektir. Araştırma nicel araştırma desenlerinden tek gruplu yarı deneysel desen olarak tasarlanmıştır. Çalışma grubu amaçlı örnekleme yöntemlerinden kolay ulaşılabilir örneklem yöntemiyle belirlenmiş, bir devlet üniversitesinde öğrenim gören 68 sınıf öğretmeni adayından oluşmaktadır. Uygulama süreci 3 aşamada gerçekleştirilmiştir. Her aşamanın başlangıcında ısınma çalışmalarına yer verilip ilk aşamada masalın genel özellikleri ve eğitimdeki kullanım yerlerine değinilmiş, ikinci aşamada farklı yazarlar tarafından oluşturulmuş masallar örnek olarak incelenmiş, aynı masalın farklı bakış açılarıyla nasıl ele alındığı hakkında konuşulup katılımcı görüşleri alınarak oturum sonlandırılmıştır. Son aşamada drama çalışmaları ile masal çalışmaları birlikte ele alınmış ve sınıf öğretmeni adaylarından özgün masallar yazmaları istenmiştir. Araştırmanın verileri katılımcıların kendi yazdıkları masallardan oluşmaktadır. Veriler 9 kategoriden oluşan değerlendirme formu yardımıyla analiz edilmiştir. Sonuç olarak sınıf öğretmeni adaylarının masal hakkında teorik olarak bilgi sahibi olsalar da uygulama aşamasında yazdıkları masalların yeterli özgünlüğe ulaşamadığı görülmüştür.
\end{abstract}

Anahtar Kelimeler: Masal, drama, sınıf öğretmeni, yazma

\section{Effects of Drama on Tale Writing Skills of Primary School Teacher Candidates}

\begin{abstract}
The aim of this study is to examine the tales written by the primary school teacher candidates by using constructionist writing and drama and story building methods. The study was designed as a one-sample quasi-experimental design of quantitative research patterns. The study group was defined through convenience sampling of purposeful sampling methods and it comprises 68 primary teacher candidates studying in a state university. The application process was carried out in 3 stages. At the beginning of each stage, warm-ups took place. The general characteristics of the tale and the places of use in education were mentioned at the first stage. At the second stage, tales, set up by different authors, were examined as examples and discussions were held on how a same tale were handled from different perspectives and the session were finished by acquiring the views of the participants. At the last stage, the drama and the tale studies were examined together and the primary school teacher candidates were asked to write original tales.
\end{abstract}

\footnotetext{
* Doç. Dr., Düzce Üniversitesi Eğitim Fakültesi Sınıf Eğitimi Bölümü, Düzce, fatihcetincetinkaya@gmail.com, ORCID: 0000-0002-9843-6747

** Yüksek Lisans Öğrencisi, Düzce Üniversitesi Eğitim Fakültesi Sınıf Eğitimi Bölümü, Düzce, bakitopcam@icloud.com, ORCID: 0000-0002-3985-4113

*** Yüksek Lisans Öğrencisi, Düzce Üniversitesi Eğitim Fakültesi Sınıf Eğitimi Bölümü, Düzce, muhammetsnmz41@gmail.com, ORCID: 0000-0001-6516-7635
} 
The data of the research consisted of tales of the participants. The data were analyzed with the evaluation form consisting of 9 categories. As a result, although the primary school teacher candidates had theoretical knowledge about tale, it was conferred that the tales they wrote during the application stage did not reach enough originality.

Keywords: Tale, drama, primary school teacher, writing

\section{Giriş}

Masallar insanların hayal güçlerini yansıtan hikâyelerdir. Masallarda bir toplumun örfadetleri, gelenekleri, görenekleri, duygu ve düşünceleri, kısaca insana ait değerleri anlatılır (Çılgın, 2007). Masallar bu değerleri anlatırken hayal gücünden yararlanmakta ve gerçekleri dolaylı olarak eserlere yansıtmaya imkân vermektedir. (Propp, 2001). Masallardaki anlatım dili, masalların içeriği, kahramanlar ve olağanüstü olayların etkili bir şekilde kullanılması, masalların çocuklar ve yetişkinler tarafından ilginç bulunan bir sanat ürünü olmasını sağlamaktadır (Yalçın \& Aytaş, 2008). Masal kendi içerisinde çeşitli sınıflara ayrılmakta ve bu sınıflama içerisinde edebi masallar bölümünde yapma masallar bulunmaktadır (Yardımcı, 2004). Yapma masallar kaynağını halk masallarından almaktadır ve bu türde önemli olan; yazarın kendi duygu, düşünce ve en önemlisi de yazarın hayal dünyasının yansıtılmasıdır (Altunkayak, 2012). Yapma masallar kişinin kendi hayal gücünü yansıtması yönüyle içerik zenginliği sağlamakta, sunduğu içerik zenginliği çocuğa farklı hayal dünyalarının kapılarını açmaktadır.

Masal çeşitli yönleriyle çocuğun eğitimini desteklemekte, çocuğu hayata hazırlamaya katkı sağlamakla birlikte, kendisi ve çevresi ile barışık bir birey olarak yetişmesine ortam hazırlamakta aynı zamanda okunan ya da dinlenen masalla kendisini özdeşleştiren çocuk adeta masalı yaşamaktadır (Karatay, 2007; Özkan, 2014). Masallar çocukları kendi hayal dünyalarında sürüklerken çocukların yeni fikirler üretmesini kolaylaştırmakta ve kendisini masalla özdeşleştiren çocuğu gerçek dünyadan soyutlamamaktadır (İşnas, 2011).

Çocukları ve gençleri hayata hazırlayan bir diğer unsur da dramadır. Dramada yer alan teknikler ve dramanın uygulama şekli çocuğun sosyal, bilişsel ve duyusal gelişimine katkı sağlamakla birlikte kişinin kendini ifade etme becerisini de geliştirmektedir (Benson, 2008; Ginsburg, 2007; Lindsey \& Colwell, 2003). Ancak drama yöntemi bu becerilerin gelişimini sağlamak için bireyin aktif katılımını gerektirir (Chalmers, 2007; Dayton, 1990; Zipes, 2004). Masalın olaya dayalı bir metin olma özelliği, onu hareket, çatışma ve doğaçlama gibi unsurlara sahip bir ürün yapmasının yanında canlandırma için de kullanımını kolaylaştırmaktadır (Kara, 2011). Masalı eğitim-öğretim faaliyetlerinde daha kullanılabilir hale getirmek ve etkileşimli bir ortam oluşturmak için masal ve drama yöntemlerinden eş zamanlı olarak yararlanılabilir (Tanrıkulu \& Yoğurtçu, 2018).

Drama yöntemini masalla ilişkilendirerek yapılan yazınsal çalışmaların, özgünlüğü ve hayal gücünü arttırdığı düşünülmektedir (Ataman, 2006). Çocuğun üretkenliğini ve hayal gücünü geliştirme 
drama ve oluşturmacı yazma çalışmalarında ortak hedef olduğu için yazma ve drama çalışmaları birlikte kullanılabilir (Susar Kırmızı, 2015). Oluşturmacı yazma; hayal gücünden yararlanarak, dış dünyadan elde edilen izlenimleri herkesten farklı bir şekilde ortaya koymak, akıcı, hoşlanarak ve zevk alarak yazarken standartların dışına çıkmak olarak tanımlanmaktadır (Küçük, 2007; Temizkan, 2010; Güleryüz, 2006; Oral, 2003). Oluşturmacı yazmanın önemli bir özelliği ise bireyin özgünlüğünü harekete geçirmesinin yanı sıra hayal gücünü kullanarak, kendi yaşantıları ve deneyimlerine aktarmaya olanak vermesiyle birlikte gerçekleşmesi mümkün olan veya olmayan çeşitli durumları, farklı yazın türleri ile aktarma fırsatı sunmasıdır (Chenfeld, 1978; Root \& Steinberg, 1996).

Oluşturmacı yazma ve drama yöntemleri ile beraber kullanılabilecek bir diğer yöntem öykü (öykü, roman ve masal) oluşturmadır. Temizkan (2011) yazma çalışmalarında öğrencilerin kendilerini anlatabilecekleri en uygun yazınsal anlatım türlerinden birisi olarak öyküyü işaret etmektedir. Drama ile öykü oluşturma öykünün öğrencinin özgünlüğüne etkisinden yola çıkarak geliştirilir. Buradaki öykü kavramı, öykü türünün dramatize edilmesinden ziyade olaya dayalı metinlerin (masal, hikâye, anı, fıkra, destan) canlandırılmaya uygunluğu açısından ele alınmasıdır (Kara, 2011). Dramatik çalışmaların amacına ve şekline göre öykü oluşturma farklı şekillerde gerçekleştirilebilir (Bertiz, 2005). Drama ile öykü oluşturma 4 başlık altında toplanmıştır (Kara, 2010). Bu başlıklar; doğrudan bir metin ya da olaydan öykü oluşturma, yarım bırakılmış öyküyü tamamlama, mevcut öykünün öğelerini değiştirme, çağrışım ve doğaçlama yoluyla öykü oluşturma şeklindedir.

Bu sınıflama içerisinde hayal gücünü kullandıran ve özgünlüğü en fazla ortaya çıkaran yöntemin çağrışım ve doğaçlama yoluyla oluşturulan öyküler olduğuna ayrıca değinilmektedir (Kara, 2010). Çağrışım ve doğaçlama yönteminin bu özelliği, onu yazma çalışmalarında kullanılabilirlik açısından diğer yöntemlere göre daha avantajlı kılmaktadır. Bu bağlamda çocuğun hayal gücünü ve özgünlüğünü artırırken aynı zamanda kendisi ve çevresi ile barışık bir birey olarak yetişmesini sağlamak için çocuğu, drama ile öykü oluşturma yöntemleri kullanılarak oluşturulmuş olaya dayalı metinlerle karşı karşıya getirmek yarar sağlayacaktır.

Olaya dayalı metinlerden biri olan masalın, okul öncesi, okul dönemi veya okul sonrası, tüm eğitim kademelerinde, özellikle dil edinimi, dilin aktif kullanılması, dilin gelişimi ve dil farkındalığı açısından önemi açıkça görülmektedir (Karatay, 2007). Masalların yetkinliğini kavramış bir yetişkin tarafından çocuklara aktarılması onların hem sanat zevklerine hitap edecek hem de onları bilişsel yönden geliştirecektir. Bununla beraber çocukların, terbiye, saygı ve ahlak gibi değerleri, önceden çözümlenip hazırlanmış bir kitaptan ya da yetişkinden öğrenmeleri de olanaksızdır (Yılmaz, 2012). Çocukların ilk olarak ailelerinden dinledikleri hikâyeler, masallar ve fabllar; ilköğretim çağına geldikleri zaman okuma-yazma öğretme sürecinde öğretmenler tarafından kullanılır ve öğrencilerin bu metinlerle olan ilişkileri devam etmiş olur (Bakken \& Whedon, 2002). Masalların önemi ve işlevi göz 
önüne alındığında masal okuma ve yazma konusunda yetkin ve becerikli olan bir sınıf öğretmeninin bu materyali etkili olarak kullanması önem arz etmektedir.

Uluslararası alan yazın tarandığında bu alanda yapılan çeşitli çalışmalara rastlanmıştır. Cheung, Tsans ve Tse (2011) ilkokul öğretmenlerinin oluşturmacı yazma becerisinin kazanılmasına ilişkin görüşlerini ve bu becerinin öğrencilere nasıl kazandırılacağını, Barbot, Donato, Grigorenko, Randi ve Tan (2012) farklı alan uzmanlarından faydalanarak çocukların oluşturmacı yazma çalışmalarındaki temel bileşenleri, Bayraktar ve Okvuran'ın (2012) drama etkinliklerinin ilkokul öğrencilerinin oluşturmacı yazma becerileri üzerindeki etkisini, Bhamani, Nasir ve Naqvi'nin (2013) ön test-son test kontrol gruplu çalışmasında oluşturmacı yazma etkinliklerinin 5. Sınıf öğrencilerinin yazma becerilerine nasıl etki ettiğini incelemiştir. Beydemir (2010) ve Susar Kırmızı (2009) oluşturmacı yazma çalışmalarının yazmaya yönelik tutuma etkisini araştırmış, Göçer (2010) temel kompozisyon kurallarını 9 başlık altında toplamış ve öğrencilere oluşturmacı yazma için gerekli olan becerilerin kazandırılması üzerinde durmuştur. Ak (2011) ve Kapar Kuvanç (2008) ön test-son test deney kontrol gruplu deneysel desenli çalışmalarında oluşturmacı yazma tekniklerinin Türkçe dersine ilişkin etkisini, Duran (2010) oluşturmacı yazma yaklaşımının uygulandığı sınıfların klasik teknikler uygulanan sınıflara nazaran yazılı anlatım becerileri arasında bir fark olup olmadığını, Akkaya (2014) anket yöntemini kullanarak ilkokul öğretmenlerinin yazarlık ile ilgili görüşlerini tespit etmeye çalışmıştır. Temizkan (2011) oluşturmacı yazma faaliyetlerinin hikâye yazma becerisine etkisini, Calp (2013) oluşturmacı yazma ve serbest yazma tekniğine göre oluşturulan kompozisyonların yazılı anlatımın niteliği açııından farklılaşıp farklılaşmadığını, Karakuş Aktan (2013) 9. Sınıf öğrencilerinin yazma becerilerini çeşitli değişkenlere göre farklılaşıp farklılaşmadığını; Türkel (2013) dramanın oluşturmacı yazma başarısına ve yazmaya yönelik tutumuna etkisini incelemiştir.

Ulusal alanyazın incelendiğinde sınıf öğretmenlerinin masal yazma becerilerini irdeleyen bir çalışmaya rastlanmamıştır ancak drama ve masalın eş zamanlı olarak kullanıldığı ve öğretmenlerin masal hakkındaki düşüncelerini inceleyen çalışmalar bulunmaktadır. Tanrıkulu ve Yoğurtçu (2018) özel yetenekli öğrencilerin eğitiminde masalların drama yöntemi ile işlenmesinin Türkçe dersine etkisini araştırmış, araştırma sonucuna göre drama yöntemi ve masal eş zamanlı uygulandığında öğrencilerin tutumlarının olumlu yönde etkilendiği tespit edilmiştir. Kara (2011) ise Türkçe dersinde drama ile öykü oluşturma yöntemini öğretmen görüşleri ile değerlendirmiş, öğretmen görüşlerinin drama ile öykü oluşturma yönteminin fayda sağlayacağı yönünde birleştiği sonucuna ulaşmıştır. Terzioğlu Ünveren (2018)'in Yazma becerisi etkinliklerinde algısal öğrenme ve drama ilişkisini araştıran benzer çalışmasında drama ve algısal öğrenmenin birlikte kullanıımasının anlatımda zenginlik ve kelime sayısında artış meydana getirdiği tespit edilmiştir. Oğuz (2017) yüksek lisans tez çalışmasında masalları birleştirme yoluyla ortaokul öğrencilerinin yazma becerilerini incelemiş ve 
oluşturmacı yazma derslerinin öğrencilerin nitelikli masal oluşturma durumlarına katkı sağladığını aktarmıştır. Okul öncesi öğretmenlerinin masalların çocuk gelişimi üzerindeki etkisini inceleyen Şahin (2011) çalışmasında öğretmen görüşlerinden yararlanmış, öğretmen görüşlerinde masalın tanımına ilişkin bir farklılaşma gözlemlerken, çocuklara yaşlarına uygun masallar anlatmanın yararlı olduğu konusunda bir bütünlük sağlandığı sonucuna yer vermiştir. Cengiz ve Duran'ın (2017) masallardaki değerler üzerine yaptıkları çalışmada masal ve hikâye kitaplarının içeriklerine öğretmenlerin de katkı sağlaması gerektiği sonucuna varılmıştır. Bu çalışmada ise sınıf öğretmeni adaylarının oluşturmacı yazma ve drama ile hikâye oluşturma teknikleri kullanılarak masal yazmaları sağlanmış ve ortaya çıkan masallar değerlendirilmiştir.

\section{Yöntem}

\section{Araştırmanın Modeli}

Bu araştırmada, sınıf öğretmeni adaylarının oluşturmacı yazma ve drama ile hikâye oluşturma yöntemi kullanılarak yazdıkları masalları değerlendirmek amacıyla nicel araştırma yöntemlerinden deneysel desenler kullanılmıştır. Deneysel desenler özel bir uygulamanın sonuç üzerindeki etkisini belirlemeyi hedefler (Creswell ve Plano Clark, 2011). Araştırma tek gruplu yarı deneysel desen olarak tasarlanmıştır. Bu şekilde tasarlanan desenlerde belirlenen gruba önce deneysel bir işlem uygulanır, sonrasında ölçüm yapılır (Cook ve Campbell, 1979).

\section{Araştırma grubu}

Araştırma 2018-2019 yılı güz döneminde bir devlet üniversitesi sınıf öğretmenliği bölümünde öğrenim gören 68 katılımcıyla yürütülmüştür. Çalışma grubu belirlenirken amaçlı örneklem yöntemlerinden kolay ulaşılabilir durum örneklemesi tercih edilmiştir. Bu örneklem seçiminde araştırmaya ekonomiklik kazandırması sebebiyle araştırmacı ulaşılması kolay durumları seçmektedir (Glesne, 2015). Veri toplama aracı olarak sınıf öğretmeni adaylarının kendi yazdıkları masallar kullanılmıştır.

\section{Verilerin Toplanması}

Araştırmanın uygulama basamağı 3 oturumdan oluşmaktadır. Her oturuma başlamadan önce ısınma etkinlikleri gerçekleştirilmiştir. Illk oturumda katılımcılara masalların genel özelliklerinden bahsedilip aşama aşama yapma masalın özellikleri anlatılmıştır. Aynı zamanda sınıf öğretmenlerinin masalı nasıl kullanacakları ve masalların eğitimdeki yeri ayrıntılı bir şekilde aktarılmıştır. Bu süreçte drama teknikleri ve masal ögeleri birlikte ele alınmış, drama ve masal ilişkilendirilerek katılımcıların bağ kurması sağlanmıştır. 
İkinci oturumda ısınma etkinliklerinin ardından klasik masalları, yapma masalları ve aynı masalın farklı bakış açılarıyla oluşturulması durumunda oluşan farklı betimlemeleri aktarabilmek amacıyla örnek masallar seslendirilmiştir. Charles Perrault tarafından yazılmış olan Kırmızı Başlıklı Kız kitabı seslendirildikten sonra, aynı masalın farklı bir bakış açısıyla oluşturulduğu Sara Şahinkanat tarafından yazılmış olan Kim Korkar Kırmızı Başlıklı Kızdan kitabı seslendirilmiş; ardından Terasa Heaphy tarafından yazılan Kırmızı Başıkı Küçük Kız kitabı seslendirilmiştir. Böylelikle öğretmenin masalı öğretim materyali haline getirmek için yapabilecekleri, hayal gücünü kullanma, masalın çocuğun dünyasına dokunması, öğrencinin eleştirel düşünmesine yardımcı olma gibi konularda araştırmacı tarafından somut örnekler gösterilmiş, katılımcılarla araştırmacı bu örnekler üzerine konuşma imkânı bulmuştur. Charles Perrault tarafından yazılmış olan Külkedisi ve Terasa Heaphy tarafından yazılmış olan Küçük Külkedisi kitapları seslendirilerek konu pekiştirilmiş; katılımcılardaki duygu durumları alınarak oturum sonlandırılmışır.

Son oturumda ise uygulamaya başlanmadan önce ısınma etkinlikleri gerçekleştirilmiş, katılımcılarla zihinsel bir hazırlık yapılmıştır. Ardından çağrışım ve doğaçlama yönteminin kullanılabilmesi, yapma masalın niteliklerinin ön plana çıkabilmesi için dikdörtgen prizma şeklinde tasarlanmış olan dış yüzeyinde denizyıldızı, ahtapot, balık ve denizanası gibi çeşitli deniz canlılarının 2 boyutlu görsellerinin yer aldığı; iç yüzeyinde ise ev, otobüs, ağaç gibi 3 boyutlu nesnelerin yer alığı masal kutusu katılımcılara gösterilmiştir. Masal kutusunun içinde hamurdan yapılmış kahraman figürleri bulunmaktadır. "Neresi olmasını istiyorsanız orası, kimler olmasını istiyorsanız onlar, ne zaman olmasını istiyorsanız o zaman ve neler yaşanmasını istiyorsanız onların yaşandığı bir masal" şeklindeki yönerge ile katılımcıların masal kutusunu incelemeleri istenmiştir. Katılımcıların hayal dünyalarındaki ögelerin harekete geçmesi, çağrışımların gerçekleşmesi amacıyla zamanda bir kısıtlama yapılmadan katılımcıların istedikleri kadar ara vererek masallarını oluşturmaları sağlanmıştır.

Uygulama esnasında ihtiyaç duyulması halinde kâğıt, kalem, silgi gibi materyaller tedarik edilmiş; oluşturulan kurgusal ortamın bozulmaması için çaba sarf edilmiştir. Uygulama tamamlandıktan sonra analiz edilmek üzere yapma masallar toplanmış ve tüm katılımcılara teşekkür edilmiştir.

\section{Verilerin Analizi}

Öğrencilerin yazma başarılarını ölçmek amacıyla alan yazındaki çeşitli yazı değerlendirme ölçekleri (İnce, 2006; Karateke, 2006; Maltepe, 2006; Öztürk, 2006; Susar Kırmızı, 2008; Temizkan, 2011) incelenmiştir. Yamaç'ın (2015) geliştirdiği dijital hikâye puanlama anahtarı uyarlanarak kullanılmıştır. Puanlama anahtarını geliştiren araştırmacının da aralarında bulunduğu 3 uzmandan 
görüşleri alınarak puanlama anahtarındaki dijital ögeler çıkarılmıştır. Sonuç olarak ölçekte bulunan 13 kategoriden 4'ü uygun bulunmamış, kalan 9 kategori üzerinden yeniden uzman görüşüne başvurulmuştur. Kategoriler, (1)_kategori gerekli, (2) kategori yararlı ancak yeterli değil, (3) kategori gereksiz şeklinde değerlendirilmiş; uzmanların kapsam geçerliliğine ilişkin görüşlerinin uyum oranı \%85 ile \%100 arasında değişmiştir. Sonuç olarak çalışmadan elde edilen veriler; heyecanlandırıcı soru, duygu, orijinallik ve özgünlük, ekonomi, tempo, bakış açısı, karakterler, olay örgüsü ve masalın amacı olmak üzere 9 kategori de analiz edilmiştir. Heyecanlandırıcı soru kategorisiyle, masalların ne derecede merak uyandırdığı ölçülmeye, duygu kategorisinde masalın bir duygu yansıtıp yansıtmadığı, orijinallik ve özgünlük kategorisiyle masalların özgün olup olmadığı, ekonomi kategorisinde masalların uzun ve kısa olma durumları değerlendirilmiştir. Tempo kategorisiyle masalın akıcılığı, bakış açısı kategorisinde masalların yansıttığı bakış açıları, karakterler kategorisinde masalın kahramanların nitelikleri, olay örgüsü kategorisinde masallarda olması gereken bölümlere ne ölçüde yer verildiği, masalın amacı kategorisinde masalların yazııış amaçlarının anlaşılabilirliği incelenmiştir.

\section{Bulgular}

Araştırma kapsamında elde edilen masalların niteliğini belirlemek amacıyla metinler 9 kategori üzerinden değerlendirilmiştir. Analiz edilen masallardan elde edilen bulgular şu şekildedir;

Tablo 1. Heyecanlandırıcı soru

\begin{tabular}{ll}
\hline & $f$ \\
\hline $\begin{array}{l}\text { Masalda okuyucunun dikkatini canlı tutan ve zihninde soru işaretleri } \\
\text { uyandıran bir soru yoktur. }\end{array}$ & 25 \\
Masal okuyucunun zihninde bir soru oluştursa da tam olarak ne & 28 \\
olduğu anlaşılmamaktadır. & 14 \\
Masalda okuyucunun zihninde beliren bir soru bulunmaktadır. & 1 \\
Masalda okuyucunun dikkatini masalın sonuna kadar canlı tutan ve & \\
okuyucunun zihninde merak uyandıran bir soru vardır ve masalın & \\
sonunda cevaplanmaktadır.
\end{tabular}

Araştırma sonucunda elde edilen bulgulara baktığımızda öğretmen adaylarının yazdıkları masalların 25'inin okuyucuyu masal içinde sürükleyen "soru" unsurunu yeteri kadar içermediği görülmektedir. Soru unsurunu içerisinde barından 28 masalda ise sorunun okuyucu tarafından kavranılmasının güç olduğu tespit edilmiş, bu durum yazılan masalların 53 tanesinde yani toplam masal sayısının \%77 sinde problemin kurgulanmamış ya da yeterince iyi yansıtılamamış olduğunu işaret etmektedir.

Bunun yanında 14 masalda soru unsuru iyi derecede işlenmiş; 1 masalda ise sorun, okuyucu tarafından net olarak anlaşılacak şekilde düzenlenmiştir.

Tablo 2. Duygu

\begin{tabular}{ll}
\hline & $f$ \\
\hline Masalın okuyucuya hissettirmek istediği bir duygusu yoktur. & 24 \\
Masalda verilmek istenen bir duygu olduğu hissedilse de açı bir & 29 \\
şekilde ne olduğu anlaşılmamaktadır. &
\end{tabular}


Masal okunduğunda vermek istediği bir duygu olduğu görülmektedir. 15 Masalın anlatım şekli ve olay örgüsü masalın vermeye çalıştığı duyguyu yansıtmaktadır. Masal açık bir şekilde okuyucuya hissettirmek istediği bir duyguya sahiptir.

Masallar yansıttıkları duygular açısından değerlendirildiğinde, masalların 24'ünün okuyucudaki hisleri harekete geçirecek bir duygu barındırmadığı sonucuna varılmaktadır. Yazılan 29 masalda, metne duygu katılmaya çalışılmıs ancak okuyucuya tam olarak ulaştırılamamıştır. Diğer 15 masalda verilmek istenen duygu ise metnin içerisinde bulunmaktadır. Ayrıca duygunun hiçbir masalda okuyucuya tam olarak yansıtılamadığı görülmektedir.

Tablo 3. Orijinallik ve özgünlük

\begin{tabular}{ll}
\hline Masalın orijinal ve özgün olduğu söylenemez. & $f$ \\
Masal okunduğunda biraz orijinal ve özgün olduğu görülmektedir. & 14 \\
Masal okunduğunda orijinal ve özgün olduğu görülmektedir. & 42 \\
Masal baştan sona tamamıla özgündür. İzlendiğinde özgün ve orijinal & 12 \\
olduğu hemen anlaşılmaktadır. & - \\
\hline
\end{tabular}

Yazılan masalların 14'ünde herhangi bir orijinallik bulunmamakta ve masallar genellikle gündelik yaşamdaki sıradan olayları işlemektedir. Bu durum yazılan masalların \%20 sinin özgün olmadığını göstermektedir. Kısmen özgün olan masalların sayısı ise 42 olmakla birlikte bu masallar \%61 gibi önemli bir çoğunluğu temsil etmektedir. Bununla beraber 12 masalın içeriği oldukça özgün kurgulanmıştır.

Tablo 4. Ekonomi

\begin{tabular}{ll}
\hline & $f$ \\
\hline Masaldaki detaylar ekonomik değildir. Ya çok uzun ya da çok kısadır. & 29 \\
Masalda detaylar bulunmaktadır ve bazı bölümleri biraz daha & 30 \\
düzeltilmeye ihtiyaç duymaktadır. & 9 \\
Masal genellikle uygun miktarda detaya sahiptir. & - \\
Masal en iyi düzeyde detaylara yer vermektedir. Masal ne çok uzun ne & \\
de çok kısadır.
\end{tabular}

Veriler ekonomi kategorisinde incelendiğinde, masalların \%50'den fazlasında yazarların sözcük seçerken veya anlatmak istediği olayı yazıya aktarırken çeşitli sorunlarla karşılaştığı görülmektedir. Yazarların anlatmak istedikleri olayı toparlayıp uygun detaylarla süsleyerek bir bütün halinde yazıya aktardığı yalnızca 9 masal bulunmaktadır.

Tablo 5. Tempo

\begin{tabular}{lc}
\hline & $f$ \\
\hline Masalın temposu olay örgüsüne uygun değildir. Okuyucuyu masala & 26 \\
çekmemektedir. & 31 \\
Masalın temposunun olay örgüsüne uygun olduğu söylense de &
\end{tabular}


Sınıf öğretmeni adaylarının yazdığı masallar akıcılık ve anlaşılırlık açısından ele alındığında 68 masalın 26'sının içerisindeki kurgunun okuyucunun ilgisini çekemediği ve bu yüzden de takip edilmesinin zor olduğu ortaya çıkmaktadır. Yazılan 31 masalda ise kurgu açısından bir sorun olmadığı ancak anlatılan olayın okuyucunun dikkatini çekecek şekilde tasarlanmadığı belirlenmiştir. Masallar içerisinde dikkat çekici ögeleri barındıran masalların sayısı ise 11 'dir. Yazılan masallarda hem olayları dikkatli kurgulanan hem de dikkat çekici ögeleri barındıran masal bulunmamaktadır.

Tablo 6. Bakış açısı

\begin{tabular}{ll}
\hline Bakış açısını ayırt etmek güçtür. & $f$ \\
Bakış açısı vardır ama amaçtan ve masaldan kopuktur. & 28 \\
Bakış açısı vardır ama bazı bölümlerinde amaç ile kopukluklar vardır. & 30 \\
Bakış açısı iyi geliştirilmiştir ve masalın başından sonuna amacını & 9 \\
destekleyici niteliktedir. & 1 \\
\hline
\end{tabular}

Katılımcıların yazdıkları masallar incelendiğinde 28 katılımcının -toplam katılımcı sayısının \%41'inin- yazdıkları masallarda bakış açısını tespit etmenin güç olduğu, \%44'ünün yazdıkları masallarda bakış açılarının amaç ve hikâyeden kopuk olduğu ve \%13'ünün ise bakış açısını yansıttığı ancak yer yer bakış açısında kopukluklar olduğu tespit edilmiştir. Yalnızca 1 katılımcının masalında bakış açısı iyi geliştirilmiş ve amacı destekler nitelikte kurgulanmıştır.

Tablo 7. Karakterler

\begin{tabular}{ll}
\hline & $f$ \\
\hline Masalda karakterler belirsizdir. & 1 \\
Masalda karakterler bellidir ancak yalnızca isimleri verilmiştir. & 44 \\
Masalda karakterler isimleri ile birlikte verilmiş ancak karakterler & 19 \\
hakkında çok az bilgi verilmiştir & \\
$\begin{array}{l}\text { Masalda karakterler isimleri ile birlikte ayrıntılı bir şekilde tasvir } \\
\text { edilmiştir. }\end{array}$ & 4 \\
\hline
\end{tabular}

Yazılan masallardaki karakterler değerlendirildiğinde, 44 katılımcının yazdığı masalda yani yazılan masalların \%64'ünde yalnızca karakterlerin isimlerine yer verilip özelliklerinden bahsedilmediği tespit edilmiştir. Masalların \%27'sinde ise karakterler hakkında bilgi verilse de karakteri yansıtmaya yeterli olmadığı ve yalnızca $\% 5^{\prime}$ inde karakterlerin ayrıntılı bir şekilde tasvir edildiği belirlenmiştir.

Tablo 8. Olay örgüsü

Masalın döşeme, serim, düğüm, çözüm ve dilek bölümlerine sahip 7 olduğu söylenemez. 
Masalın döşeme, serim, düğüm, çözüm ve dilek bölümleri dağınık bir

biçimde verilmiştir.

Hikâyenin döşeme, serim, düğüm, çözüm ve dilek bölümleri iyi

geliştirilse de ayrıntılara sahip değildir.

Hikâyenin döşeme, serim, düğüm, çözüm ve dilek bölümleri çok iyi

geliştirilmiştir ve detaylara sahiptir.

Masallar analiz edildiğinde olay örgüsünü net bir şekilde ortaya koyan masalların sayısının azlığı görülmektedir. 7 masalda, masallarda olması gereken bölümlerden herhangi birinin eksik olduğu, yazılan masaların \%64 gibi büyük bir çoğunluğunda masalın taşıması gereken bölümlerin net bir şekilde ortaya koyulmadığı tespit edilmiştir. Ayrıca 17 masalda bölümler net bir şekilde ortaya koyulmuş ancak bu masallarda da bölümlerin kendi içlerinde yeterince geliştirilmediği belirlenmiştir. Yazılan masalların hiçbirinde bölümlerin net bir şekilde ortaya konulamadığı bulgusuna ulaşılmıştır.

Tablo 9. Masalın amacı

\begin{tabular}{lc}
\hline Masalda açık bir amaç yoktur. Ana fikir anlaşımamaktadır. & $f$ \\
Masalda bir amaç olduğu hissedilse de açık bir şekilde okuyucunun & 37 \\
zihninde belirdiği söylenemez. & 17 \\
Yazarın masalda bir amaca sahip olduğu ve vermeye çalıştığı bir ana & 12 \\
fikir olduğu görülmektedir. & \\
Masalın yazarı açık bir amaca sahiptir. Masalda vermek istediği ana \\
fikir açık bir şekilde anlaşılmaktadır.
\end{tabular}

Masallar amaçları açısından incelendiğinde 37 masalda herhangi bir ana fikir tespit edilememiştir. 17 masalda bir amaç olduğu sezilse de amacın net bir şekilde ortaya konulmadığı söylenebilir. Masalların \%17'sinde ana fikir okuyucular tarafından anlaşılabilecek şekildedir. Fakat okuyucuların ana fikri ve masalın amacını anlayabileceği masal sayısı yalnızca 2'dir. Yazılan 54 masalın geliştirilip bir amaç doğrultusunda yeniden tasarlanması gerekmektedir.

Tablo 10. Katılımcıların 36 tam puan üzerinden aldıkları puanlar

\begin{tabular}{ll}
\hline & $f$ \\
\hline $9-15$ arası puan alan katılımcılar & 24 \\
$16-20$ arası puan alan katılımcılar & 24 \\
$21-25$ arası puan alan katılımcılar & 19 \\
$26+$ & 1 \\
\hline
\end{tabular}

Tablo 10’a bakıldığı zaman, katılımcıların en fazla 36 puan alabildiği değerlendirme ölçütüne göre değerlendirilen masalların 24'ü 9-15 puan, 24'ü 16-20 puan ve 19'u 21-25 puan aralığında yer almıştır. Bunlara ek olarak 1 masalın bu değer aralığını aştığı tespit edilmiştir.

\section{Tartışma, Sonuç ve Öneriler}

Sınıf öğretmeni adaylarının çağrışım ve doğaçlama yöntemi ile yazdıkları masalları inceleyen bu çalışmanın bulguları 9 kategoride değerlendirilmiştir. Sonuç olarak sınıf öğretmeni adaylarının 
masal yazma becerilerinin hiçbir kategoride yeterli seviyeye ulaşamadığı tespit edilmiştir. Yapılan çalışmaya benzer bir çalışma gerçekleştiren Akkaya (2014) ilkokul öğretmenlerinin oluşturmacı yazma ile ilgili görüşlerini belirlemeye çalışmıs ve gerçek anlamda oluşturmacı yazma teknikleri hakkında yeterli bilgiye sahip olan öğretmen sayısının az olduğu sonucuna varmıştır. Şahin (2011) yine benzer bir çalışmada okulöncesi öğretmenlerinin masalı tanımlama aşamasında benzer fikirler ortaya koyamadıklarını aktarmaktadır. Karakuş Aktan (2013) 9. sınıf öğrencilerin oluşturmacı yazma becerilerini incelemiş, araştırmaya katılan öğrencileri yazma becerileri konusunda yetersiz bulmuştur. Akkaya (2014), Karakuş Aktan (2013) ve Şahin'in (2011) çalışmalarının sonuçlarının bu çalışmayı destekler nitelikte olduğu görülmektedir.

Maltepe (2006) doktora tezi çalışmasında, oluşturmacı yazmaya hazırlık sürecinde öğrencilerin olağan dışı yazma ve hayal gücünü etkin kullanmada yeterli seviyeye ulaşamadıklarını aktarmıştır. Öğretmenlerin Türkçe dersinde oluşturmacı yazma eserlerinin değerlendirme ve uygulama aşamalarına uygunluk gösterdiğini düşündüğünü ancak öğrencilerin bu görüşe katılmadığını belirtmiştir. Yazma sürecinin geliştirilmesindeki en zor aşamanın konu bulmak olduğu düşünülmektedir (Ataman, 2006). Ancak bu araştırmanın sonucunda sınıf öğretmeni adaylarının orijinallik ve özgünlük açısından yetersiz kaldığı tespit edilmiş; orijinal bir ürün ortaya koyma ve özgünlük açısından yetersiz olarak yetişen sınıf öğretmenlerinin, çocukların özgünlüğüne ve yeni fikirler üretmesine katkı sağlamada da yetersiz kalacağı düşünülmektedir. Maltepe'nin (2006) çalışması bu bakımdan benzerlik göstermektedir. Oluşturmacı yazma ve drama çalışmalarının özgünlüğü arttırdığı sonucuna ulaşılan çalışmalar da vardır (Ataman, 2006; Kapar Kuvanç, 2008; Kara, 2010; Oğuz, 2017; Susar Kırmızı, 2015; Tanrıkulu \& Yoğrutçu, 2018; Temizkan, 2010). Ancak bu araştırmanın uygulama aşamasında drama ve masal çalışmaları beraber kullanılsa da sınıf öğretmeni adaylarının yazdıkları masallar bu çalışmaları destekler niteliğe ulaşamamıştır.

Susar Kırmız (2009) ve Türkel (2013) çalışmalarında oluşturmacı yazma çalışmalarının yazmaya yönelik tutumu olumlu bir şekilde etkilediği sonucuna ulaşmışlardır. Tutuma olumlu yönde etki yapan oluşturmacı yazma hakkında öğretmen adayları yeterli seviyede bilgi birikimine sahip olmalıdır. Analiz edilen masallar anlatım akıcılığı, olay örgüsü zenginliği, karakter tasvirleri ve bir amaç doğrultusunda yazma konularında yeterli seviyeye çıkamamıştır. Okulöncesi dönemi için hazırlanan masal kitaplarını inceleyen Cengiz ve Duran (2017) masalların çeşitli değerler barındırdığı sonucuna varmış ve öğretmenlerin öğrencilerin kitap tercihlerine yardımcı olması gerektiğini aktarmıştır. Masaldaki anlatım akıcılığı, karakterlerin özellikleri ve konu bütünlüğü bu değerleri yansıtmakta önemli bir araçtır. Analiz edilen masalların sayılan özellikler bakımından yetersizliği aktarılmak istenen değerlerin çocuğa yeterince ulaşmasının önüne geçecektir. Sınıf öğretmeni adaylarının yazdıkları masalların anlatılan özellikler açısından geliştirilmesi gerekmektedir. 
Nasir ve diğerleri (2013) 5. Sınıf öğrencilerinin yazma becerilerini inceleyen çalışmalarında öğretmenlerin gerekli uygulamaları yaparak öğrencilerin yazma becerilerine destek olabileceğini aktarmışlardır. Bu araştırma sonucunda ise sınıf öğretmeni adaylarının yazdıkları masalların yeterli seviyede olmadığı görülmekte, bu seviyedeki öğretmenlerin çocukların yazma becerilerini geliştirmede yeterli olamayacağı düşünülmektedir. Cheung ve diğerlerinin (2011) yaptığı çalışmada öğretmenlerin teoride yazma becerilerine hâkim olduğu ancak uygulama aşamasında yeterli olmadıkları tespit edilmiştir. Bu yönüyle Cheung ve diğerlerinin çalışması bu çalışmayı destekler niteliktedir. Çalışma, uygulama aşamasında titizlikle yürütülse de yapılan çalışmalarda yetersiz sonuçlar çıkması veri toplama ve uygulama aşamasın da yaşanan aksaklıklardan kaynaklanabilir ancak sınıf öğretmenlerinin iyi masal yazabilmeleri öğrencilerin yazma becerilerini olumlu yönde destekleyecektir.

Sonuç olarak sınıf öğretmeni adayları teorik olarak masalların özelliklerine hâkim olsalar da uygulama aşamasında bu becerileri tüm yönleriyle yansıtmada sorunlar yaşamaktadır. Bu durumun sebepleri arasında sınıf öğretmenliği bölümü lisans dersleri içerisindeki drama ve çocuk edebiyatı derslerinde yeterli seviyede verim alınamaması gösterilebilir. Öğretmenlerin daha aktif öğrencilerin daha pasif katılım gösterdiği fakat bunun tam tersi olması gereken alan derslerinin içeriklerinde yapılacak güncellemeler ile birlikte öğretmen adaylarının özgünlükleri ve bakış açılarının değişebileceği düşünülmektedir. Bu yüzden sınıf öğretmenliği lisans derslerinden drama ve çocuk edebiyatı derslerinin içerikleri güncellenmeli, öğretmen adaylarının masal algıları geliştirilmeli, yapma masallar oluşturabilmeleri, masalları canlandırmaları sağlanmalı, birçok teknikle masal yazma, anlatma, canlandırma gibi konularda uzman olmaları sağlanmalıdır. Ayrıca uygulamanın görevdeki sınıf öğretmenleri ile gerçekleştirilerek bu çalışmanın bulguları ile karşılaştırılması da önemlidir. Son olarak öğretmen adaylarııı saha çalışması alanlarını genişleterek bu tür uygulamalarda tecrübe sahibi olmaları sağlanabilir.

\section{Kaynaklar}

Ak, E. (2011). Yaratııı yazma tekniklerinin ilköğretim 5. sını öğrencilerinin Türkçe dersindeki yazılı anlatım becerileri üzerindeki etkisi. (Yayınlanmamış yüksek lisans tezi). Dokuz Eylül Üniversitesi, İzmir.

Akkaya, N. (2014). Elementery teachers "Views on the creative eriting process: An Evaluation. Educational Sciences: Theory and Practice.

Altunkayak, M. (2012). ilköğretim 1. kademe Türkçe ders kitaplarında yer alan masal metinlerinin Türkçe dersinin amaçları doğrultusunda kullanımına göre öğretmen görüşleri. (Yayınlanmamış Yüksek Lisans Tezi). Çukurova Üniversitesi Sosyal Bilimler Enstitüsü, Adana.

Ataman, M. (2006). Yaratııı drama sürecinde yaratııı yazma. Yaratıcı Drama Dergisi, 1(1), 76-87.

Bakken, J., \& Whedon, C. (2002). Teaching Text Structure to Improve Reading Comprehension. Intervention In School and Clinic, 37(4), 229-233. 
Barbot, B., Tan, M., Randi, J., Donato, G., \& Grigorenko, E. (2012). Essential Skills for Creative Writing: Integrating Multiple Domain-Specific Perspectives. Thinking Skills and Creativity, 7(3), 209-223.

Başaran, M. (2003). Ilköğretim 4. ve 5. sınıflarda öğretmenlerin Türkçe derslerinde öğretim materyalleri kullanma durumları. (Yayınlanmamış yüksek lisans tezi). Gazi Üniversitesi Eğitim Bilimleri Enstitüsü, Ankara.

Bayraktar, A., \& Okvuran, A. (2012). Improving Student's Writing Through Creative Drama. Procedia-Social and Behavioral Sciences, 51, 662-665.

Benson, T. (2008). Dramatic play: bring it back. Texas Child Care, 32(2), 24-31.

Bertiz, H. (2005). Fen bilgisi öğretmen adaylarının yaratıcı dramaya yönelik tutumları ve öyküleme çalışmalarına ilişkin görüşleri. (Yayınlanmamış Yüksek Lisans Tezi). Abant İzzet Baysal Üniversitesi Sosyal Bilimler Enstitüsü, Bolu.

Beydemir, A. (2010). ilköğretim 5. Sınıf Türkçe dersinde yaratıcı yazma yaklaşımının yazmaya yönelik tutumlara, yaratıcı yazma ve yazma erişisine etkisi. (Yayınlanmamış yüksek lisans tezi). Pamukkale Üniversitesi, Denizli.

Calp, M. (2013). Serbest ve yaratıcı yazma tekniğine göre oluşturulan kompozisyonların yazılı anlatımın niteliği ve puanlama tekniği açısından karşılaştırılması. Turkish Studies, 8(9), 879-898.

Cengiz, Ş., \& Duran, E. (2017). Okul öncesi dönemine ait hikaye ve masallardaki değerlerin incelenmesi. Eğitim ve Bilim, 42(191), 205-233.

Chalmers, D. (2007). Drama 3-5: A practical guide to teaching drama to children in the foundation stage. New York: Taylor \& Francis Group.

Chenfeld, M. B. (1978). Teaching Language Arts Creatively. Inc: Harcourt Brace Jovanovich.

Cheung, W., Tse, S., \& Tsans, H. (2011). Teaching Creative Writing Skills to Primary School Children in Hong Kong: Discordance Between the Views and Practices of Language Teachers. Creative Education Foundation.

Cook, T.D. \& Campbell, D.T. (1979). Quasi-experimentation: Design and analysis issues for field settings. Chicago: Rand McNally.

Creswell, J. W., ve Plano Clark, V. L. (2011). Designing and conducting mixed methods research (2.bs.). Thousand Oaks, CA: Sage.

Çılgın, A. S. (2007). Çocuk Edebiyatı. İstanbul: Morpa Kültür Yayınları.

Dayton, T. (1990). Drama games: Techniques for self-development. Deerfield Beach, Florida: Health Communications.

Dedeoğlu Orhun, B. (2014). Estetik kavramı çerçevesinde çocuk edebiyatı. Türk Dili.

Duran, S. (2010). Yaratııı yazma yaklaşımının yazılı anlatım becerisinin gelişimine etkisi. (Yayınlanmamış yüksek lisans tezi). Trakya Üniversitesi , Edirne.

Ginsburg, K. R. (2007). The importance of play in promoting healthy child development and. MD Pediatrics, 119(1), 182-191.

Glesne, C. (2015). Becoming Qualitative Researchers: An Introduction. Boston: Pearson Education.

Göçer, A. (2010). Türkçe öğretiminde çok uyaranlı bir öğrenme ortamı oluşturmak için seçkin edebi ürünlerden yararlanma. TÜBAR(27), 341-369.

Göçer, A. (2010). Türkçe öğretiminde yazma eğitimi. Uluslararası Sosyal Araştırmalar Dergisi.

Güleryüz, H. (2006). Yaratıcı Çocuk Edebiyatı. Ankara: Pegem Yayınları. 
Ince, V. M. (2006). Ilköğretim 3,4,5,6,7 ve 8. sınıf öğrencilerinin yazılı anlatım becerilerinin ölçülmesi ve değerlendirilmesi. (Yayımlanmamış Yüksek Lisans Tezi). Muğla Üniversitesi Sosyal Bilimler Enstitüsü, Muğla.

İşnas, S. (2011). Masal türünün çocuktaki kavram gelişimine etkisi üzerine bir araştırma (Cahit Zarifoğlu örneği). (Yayınlanmamış Yüksek Lisans Tezi). Afyon Kocatepe Üniversitesi Sosyal Bilimler Enstitüsü, Afyonkarahisar.

Kapar Kuvanç, E. (2008). Yaratıcı yazma tekniklerinin öğrencilerin Türkçe dersine, ilişkin tutumlarına ve Türke dersindeki başarılarına etkisi. (Yayınlanmamış yüksek lisans tezi). Dokuz Eylül Üniversitesi, İzmir.

Kara, Ö. T. (2010). Dramayla öykü oluşturma yönteminin ilköğretim ikinci kademe Türkçe öğretimine etkisi. ( Yayınlanmamış Doktora Tezi). Selçuk Üniversitesi Eğitim Bilimleri Enstitüsü, Konya.

Kara, Ö. T. (2011). Dramayla öykü oluşturma yönteminin Türkçe dersi ikinci kademe öğrencilerinin tutumlarına etkisi. Mustafa Kemal Üniversitesi Sosyal Bilimler Enstitüsü, 8(16), 239-253.

Karakuş Aktan, E. N. (2013). Ortaöğretim öğrencilerinin yaratıcı yazma becerileri üzerine bir araştırma. Adıyaman Üniversitesi Sosyal Bilimler Enstitüsü Dergisi, 6(11), 702-732.

Karatay, H. (2004). Illköğretim II. kademe Türkçe ders kitaplarının ortak kelime kazandırma yönünden değerlendirilmesi. (Yayınlanmamış yüksek lisans tezi), Gazi Üniversitesi Eğitim Bilimleri Enstitüsü, Ankara.

Karatay, H. (2007). Dil edinimi ve değer öğretimi sürecinde masalın önemi ve işlevi. Türk Eğitim Bilimleri Dergisi, 5(3), 463-475.

Karateke, E. (2006). Yaratıcı dramanın ilköğretim II. kademede 6. sınıf öğrencilerinin yazılı anlatım becerilerine olan etkisi. (Yayınlanmamış Yüksek Lisans Tezi). Mustafa Kemal Üniversitesi Sosyal Bilimler Enstitüsü, Hatay.

Köse, A. (2004). Muş ili malazgirt ilçesi'nde anlatılan masalların çocuk eğitimine katkısı. (Yayınlanmamış yüksek lisans tezi), Selçuk Üniversitesi Sosyal Bilimler Enstitüsü, Muş.

Küçük, S. (2007). Yazılı Anlatım ve Yaratıcılık. Samsun: Ondokuz Mayıs Üniversitesi Yayınları.

Lindsey, E. W., \& Colwell, M. J. (2003). Preschoolers' emotional competence: Links to pretend and. Child Study Journal, 33(1), 39-52.

Maltepe, S. (2006). Yaratıcı yazma yaklaşımı açısından Türkçe derslerindeki yazma süreçlerinin ve ürünlerinin değerlendirilmesi. (Yayınlanmamış Doktora Tezi). Ankara Üniversitesi Sosyal Bilimler Enstitüsü, Ankara.

Nasir, L., Naqvi, S., \& Bhamani, S. (2013). Enhancing Students' Creative Writing Skills: An Action Research Project. Acta Didactica Napocensia, 6(2).

Oğuz, S. G. (2017). Masalların birleştirilme yoluyla ortaokul öğrencilerinin yaratıcı yazma becerilerinin incelenmesi. (Yayınlanmamış Yüksek Lisans Tezi). İnönü Üniversitesi Eğitim Bilimleri Enstitüsü, Malatya.

Oral, G. (2003). Yine Yazı Yazıyoruz. Ankara: Pegem Akademi.

Özkan, P. (2014). Hatay (Antakya) masallarının çocuk eğitimi açısından incelenmesi. (Yayınlanmamış Yüksek lisans tezi). Yüzüncü Yıl Üniversitesi Eğitim Bilimleri Enstitüsü, Van.

Öztürk, E. (2006). Ilköğretim beşinci sınıf öğrencilerinin yaratıcı yazma becerilerinin değerlendirilmesi. (Yayınlanmamış Doktora Tezi). Gazi Üniversitesi Eğitim Bilimleri Enstitüsü, Ankara.

Propp, V. (2001). Masalın Biçimbilimi. (M. Rıfat, \& S. Rıfat, Çev.) İstanbul: Om Yayınları.

Root, J. R., \& Steinberg, M. (1996). Those who do, can. Teachears writing, writte teaching. Illinois: National Council of English Teachers of English.

Susar Kırmızı, F. (2008). Türkçe dersinde yaratıcı drama yönteminin yaratıcı yazma başarısına etkisi ve anlatım ürünlerinin değerlendirilmesi. Ankara Üniversitesi Eğitim Bilimleri Fakültesi Dergisi, 41(özel sayı), 251257. 
Susar Kırmızı, F. (2009). Türkçe dersinde yaratıcı drama yöntemine dayalı yaratıcı yazma çalışmalarının yazmaya yönelik tutuma etkisi. Yaratıcı Drama Dergisi.

Susar Kırmızı, F. (2015). Yaratıcı drama ve yaratıcı yazma uygulamalarının yaratıcı yazma başarısına etkisi. Eğitim ve Bilim, 40(181), 93-115.

Şahin, M. (2011). Masalların çocuk gelişiminine etkileriinin öğretmen görüşleri açısından incelenmesi. Millî Folklor(89), 208-219.

Tanrıkulu, F., \& Yoğurtçu, M. (2018). Özel yetenekli öğrencilerin eğitiminde masalları drama yöntemiyle işlemenin Türkçe dersine etkisi. Uluslararası Türkçe Edebiyat Kültür Eğitim Dergisi, 7(4), 2572-2590.

Temizkan, M. (2010). Türkçe öğretiminde yaratıcı yazma becerilerinin geliştrilmesi. Türklük Bilimi Araştırmaları Dergisi (TÜBAR), Türkçe Öğretimi Özel Sayısı, 15(27), 621-643.

Temizkan, M. (2011). The effect of creative writing activities on the story writing Skill. Educational Sciences: Theory \& Practice.

Terzioğlu Ünveren, I. (2018). Yazma becerisi etkinliklerinde algısal öğrenme ve drama ilişkisi. Ana Dili Ĕgitimi Dergisi, 6(3), 652-669.

Türkel, A. (2013). Yaratıcı dramanın yaratıcı yazma başarısına ve yazmaya karşı tutuma etkisi. Buca Eğitim Fakültesi Dergisi(36), 1-11.

Uzun, R. (2009). Konya ili seydişehir ilçesi ve çevresinde anlatılan masalların çocuk eğitimine katkısı. (Yayınlanmamış yüksek lisans tezi), Selçuk Üniversitesi Sosyal Bilimler Enstitüsü, Konya.

Yalçın, A., \& Aytaş, G. (2008). Çocuk Edebiyatı. Ankara: Akçağ Yayınevi.

Yaldız, H. (2006). Masalların çocuk eğitimi açısından incelenmesi ( Sarayönü örneği). (Yayınlanmamış yüksek lisans tezi), Selçuk Üniversitesi Sosyal Bilimler Enstitüsü, Konya.

Yamaç, A. (2015). İlkokul üçüncü sınıf öğrencilerinin yazma becerilerinin gelişiminde dijital hikayelerin etkisi. ( Yayınlanmamış Doktora Tezi). Gazi Üniversitesi Eğitim Bilimleri Enstitüsü, Ankara.

Yardımcı, M. (2004). Türk Halk Edebiyatında Nesir. Ankara: Ürün Yayınları.

Yılmaz, A. (2012). Çocuk eğitiminde masalın yeri (Binbir gece masalları örneği). SDÜ Fen Edebiyat Fakültesi Sosyal Bilimler Dergisi(25), 299-306.

Zipes, J. (2004). Speaking out. Storytelling and creative drama for children. Rutledge New York- London: Master E-book.

\section{Extended Abstract}

Introduction

Tales are the stories reflecting the imagination of humankind. In the tales, general customs, traditions, thoughts and beliefs of a society, shortly values related to humankind are told (Çılgın, 2007). Tales support the education of the child in various ways, contribute in preparing him for the life, setting up an environment so that the child can grow as an individual that is at peace with himself and his surroundings. At the same time, the child consubstantiates himself with the tale told and he virtually lives it (Karatay, 2007; Özkan, 2014). The importance of tale, which is one of the event-driven texts, is easily seen concerning acquisition, active use, development of and awareness about the language in all stages of education i.e pre-school, during and after school terms (Karatay, 2007). The feature of being an event-driven text not only makes it a production having action, conflict and improvisation but also facilitates it for impersonation (Kara, 2011). Tale and drama methods can simultaneously be benefited in order to make tale more utilizable in education activities and set up an interactive environment (Tanrıkulu \& Yoğurtçu, 2018). Taking into account the importance and function of tales, it is important for the primary school teacher, who is competent and skilful and in reading and writing, to use this material effectively.

Method

This research is designed as a case study out of the qualitative research patterns in order to determine the quality of the tales written by prospective primary school teachers. It is also aimed to clearly reveal the existing situation by using survey model. The research was carried out in fall term of 2018-2019 education year 
with 68 participants studying in Department of primary school teaching in Düzce University. While defining working group, convenience sampling from purposeful sampling methods was preferred. The application process was executed in three stages. A warm-up study took place in the beginning of every stage. In the first stage, general features and the use of the tale within education was dealt while various tales written by different authors were examined, how the same tale is handled with different perspectives was discussed and the views of the participants were acquired in the second stage. During the last stage, drama studies and tale studies were embraced together and the prospective teachers were asked to write authentic tales. During the analysis of the data, various scales in the literature were examined; the scale of Yamaç (2015) was expertized, adopted and used in analysis of the data.

Result and Discussion

As a result, it was determined that the skill of tale writing of prospective primary school teachers was not on sufficient level in any stages. They have to develop their skills of writing tales. Some samples within the literature support this study while some studies do not reach the similar results. Ineligibility of skill for writing tales of the prospective primary school teacher is a sign of the fact that they will be short of contributing their students during their careers. Therefore, reading and writing studies should be supported and the prospective teachers must be made enjoy writing. 